\title{
KEMÂL YOLCULUĞU OLARAK DİNÎ TECRÜBE: GAZÂLÎ ÜZERİNDEN BİR OKUMA*
}

\author{
(1) Abdullah AKGÜLa
}

\begin{abstract}
Öz
Din Felsefesinin temel problemlerinden biri olan dinî tecrübe, bir Tanrı kanıtı olarak literatüre girmiş olsa da, mevcut tartışmalar daha çok onun mahiyeti üzerine yoğunlaşmış gözükmektedir. Söz gelimi, onun bir duygu/his tecrübesi, bir algı tecrübesi olduğu ya da aslında yașanan herhangi bir tecrübenin dinî bir yorumundan ibaret olduğu, öne sürülen belli başlı yaklaşımlardan birkaçıdır. Dinî tecrübenin mahiyetini tartışmalı kılan temel sebep, din ve tecrübe gibi geniş anlam alanına sahip iki kavramdan oluşmasıdır. Bireylerin ve geleneklerin, bu iki kavrama yükledikleri anlamlar, dinî tecrübe anlayışlarını belirleyicidir. Dinî tecrübenin bir terim olarak kullanılmaya başlanması Protestanlığın ortaya çıktığı dönemlere denk gelir. Aydınlanmanın akıl vurgusuyla birlikte, ilgili terime yüklenen anlamlar indirgenir ve terim; sebebi açıklanamayan, başkalarına aktarılamayan, epistemik değeri tartışmalı, anlık, sıra dışı yaşanmışlıklar olarak literatürdeki yerini alır. Bu makalenin ön kabulü, dinî tecrübe terimine yüklenen anlamların daraltılmış olduğu ve terimin farklı gelenekler için aynı anlamlarda kullanılmasının hatalı olduğudur. Bu makale, okurun probleme ilişkin mevcut tartışmaları bildiğini varsayar ve mevcut tartışmalara cevap yetiştirmek kaygısıyla reaksiyoner bir tavır sergilemek yerine, daha ziyade aksiyoner ve ön açıcı bir yaklaşımla konuyu ele alır. Bu makale, bir Din Felsefesi problemi olarak dinî tecrübenin literatürdekinden farklı bir okumasını sunacaktır. $\mathrm{Bu}$ doğrultuda, öncelikle Gazâlî’nin Tanrı, âlem ve insan anlayışı, dinî tecrübenin ontolojik arka planı olarak ortaya konacak; daha sonra, bu ontolojik temel üzerinden dinî tecrübe kavramına ilişkin bir tanım önerilecektir.
\end{abstract}

Anahtar kelimeler: Din Felsefesi, Dinî Tecrübe, Gazâlî, Kemâl Yolculuğu.

$$
\text { 淡淡 }
$$

\footnotetext{
* Bu çalışma, 2016 yılında Erciyes Üniversitesi Sosyal Bilimler Enstitüsü Felsefe ve Din Bilimleri Anabilim Dalında hazırlanan "Gazâlî̀de Dinî Tecrübe” başlıklı Yüksek Lisans tezinden üretilmiștir.

a Arş. Gör., Erciyes Üniversitesi, dinfelsefesi@gmail.com
} 
Abdullah AKGÜL

\section{RELIGIOUS EXPERIENCE AS A JOURNEY TO PERFECTION: AN INQUIRY INTO THE IDEAS OF AL-GHAZALI}

Religious experience is one of the fundamental problems of the philosophy of religion. Although it has entered the literature as a proof of God; discussions focus on its nature. The basic approaches to the nature of religious experience are: religious experience as a feeling, religious experience as a perception, religious experience as a comment. The main reason that makes the nature of religious experience controversial is that it consists of two concepts that have a wide range of meaning, such as religion and experience. The meanings that individuals and traditions attach to these two concepts determine the understanding of religious experience. The beginning of religious experience as a term corresponds to the periods of Protestantism. With the emphasis of Enlightenment on the mind, the meanings attributed to religious experience have been reduced and narrowed. In the literature, religious experience is unclear, cannot be transferred to others, instant and extraordinary experiences.

[The Extended Abstract is at the end of the article.]

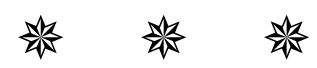

\section{Giriş}

Dinî tecrübenin, din ve tecrübe gibi geniş anlam alanına sahip iki kavramdan oluşması, belirsiz bir atıf çerçevesine sahip olmasına sebep olmaktadır. ${ }^{1}$ Bireylerin din ve tecrübe anlayışları dinî tecrübe anlayışlarını belirler. Bir terim olarak felsefe literatürüne girmesi 19. yüzyılı bulan dinî tecrübenin terimleşme sürecinin kökenleri Reform dönemine ve o dönemdeki mistisizmden destek alan Katolik eleştirilerine kadar gider. ${ }^{2}$

Reform, kilisenin inançlarına, ritüellerine ve örgütlü yapısına karşı bireysel vicdanı dile getirmiş, dinî otoriteyi tartışmaya açmış ve birey ile Tanrı arasından kiliseyi çıkarmayı amaçlamıştır. ${ }^{3}$ Bu sayede ruhban sınıfı ile diğer insanların kutsala erişimde eşitliği sağlanacak, belirli bir sınıfa özgü kabul edilen Tanrı tecrübeleri artık sıradan insanların yaşayabileceği tecrübeler haline getirilecektir. Dönemin ilk zamanlarında, bireylerin Tanrı'ya ilişkin tecrübeleri önemli sayılıp, en geçerli doğrular olarak kabul

${ }^{1}$ Sait Reçber, Tanrı'yı Bilmenin Imkanı ve Mahiyeti (Ankara: Kitabiyat Yayınları, 2004), 91 92.

2 Cafer Sadık Yaran, Dini Tecrübe ve Meûnet, Sıradan Insanların Sıradıșı Dinî Deneyimleri (İstanbul: Rağbet Yayınları, 2009), 23; Martin Jay, Deneyim Şarkıları, çev. Barış Engin Aksoy (İstanbul: Metis Yayınları, 2012), 42.

3 Richard Tarnas, Batı Düșüncesi Tarihi, çev. Yusuf Kaplan, c. 2 (İstanbul: Külliyat Yayınları, 2013), 32-34; Şinasi Gündüz, Hıristiyanlık (İstanbul: İsam Yayınları, 2013), 131-32. 
edilirken 4; Aydınlanmanın etkisi ve akıl vurgusu ile süreç, din ve dine ilişkin tecrübelerin, oldukça soyut ve manevi alana itilmesiyle sonuçlanmıştır. ${ }^{5}$

Aydınlanma döneminin dine ilişskin olduğu gibi, tecrübeye ilişkin de indirgemeci bir yaklaşımı göze çarpar. Bütüncül bir insan tecrübesinden bahsetmek yerine, empirizm ile diğer boyutları ihmal edilen tecrübe, artık özünde pozitif/pozitivist yanı ağır basan epistemolojik bir soruna indirgenir. ${ }^{6}$

Dinî tecrübenin Batı dünyasında ve bizde gelişen Din Felsefesi geleneğindeki terimleşme sürecini göz önüne aldığımızda hem din hem de tecrübe açısından indirgenmiş ve dar kalıplara sıkıştırılmış olduğunu görmekteyiz. ${ }^{7}$ Dinî tecrübe kavramına, Gazâlî özelinde bir tanım önerebilmek için, öncelikle dinî tecrübenin ontolojik arka planını ortaya koyup, sonra da mahiyetini tespit etmeye çalışalım.

\section{A. Dinî Tecrübenin Ontolojik Arka Planı}

Dinî tecrübenin özünde Tanrı-insan ilişkisi olduğunu söyleyebiliriz. Tanrı'yı tanımayı, O'nun sıfatlarıyla sıfatlanmayı, O'na yakınlaşmayı, en temelde 'kendini bilme'ye irca eden Gazâlî̀ ${ }^{8}$ söz konusu olduğunda; dinî tecrübe anlayışının temelde, insan anlayışına dayandırılabileceği kanaatindeyiz. Bu bakış açısından hareketle, öncelikle Gazâlînnin tecrübe ve din anlayışını ve daha sonra da dinî tecrübenin ontolojik arka planı olarak onun Tanrı, âlem ve insan anlayışını kısaca ele alalım.

Gazâlî tecrübeyi eserlerinde birçok yerde günlük dildeki "bilfiil yaşanan şey" anlamında kullanırken; aynı kökten türetilmiş tecrîbiyyât

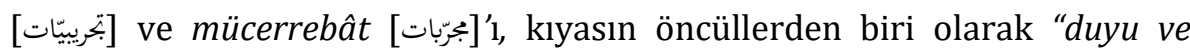
akıldan elde edilen bilgiler" anlamında kullanır. ${ }^{9}$ Her ne kadar o, eserlerinde tecrübeyi bazen epistemolojik bağlamda kullanmış olsa da dine ilişkin bir tecrübe söz konusu olduğunda, varoluşun tüm boyutlarıyla ilişkili olan bir olgudan bahseder ve dinî tecrübe mefhumuyla ilişkilendirilebilecek zevk,

4 Raymond Williams, Anahtar Sözcükler, çev. Savaş Kılıç (İstanbul: İletişim Yayınları, 2012), 153-54.

${ }^{5}$ Hakan Olgun, Sekülerliğin Teolojik Kurgusu: Protestanlık (İstanbul: İz Yayıncılı, 2006), 249.

6 Jay, Deneyim Şarkıları, 108.

7 Abdullah Akgül, "Terim Olarak Dinî Tecrübe: Tarihsel Bir İnceleme”, Social Sciences Studies Journal 4, sy 21 (2018): 3589, doi:10.26449/sssj.778.

8 Ebû Hâmid Gazâlî, Kimya-i Saâdet - Mutluluk Hazinesi, çev. A. Faruk Meyan (İstanbul: Bedir Yayınları, 2015), 17.

9 Ebû Hâmid Gazâlî, Mekâsıdu'l-Felâsife (Beyrut: Dâru'l-Kütübi'l-İlmiyye, 2008), 49; Ebû Hâmid Gazâlî, Mi'yâru'l-İlm - İlmin Ölçütü, çev. Ali Durusoy ve Hasan Hacak (İstanbul: Türkiye Yazma Eserler Kurumu Başkanlığı, 2013), 256. 
Abdullah AKGÜL

marifet, keșf, fenâ vs. kelimelerine yer verir. Biz de çalıșmamızda, tecrübe kelimesini kullanırken "duyu verileri vasıtasıyla üretilen bilgiler" anlamındaki dar kapsamlı tecrübeyi değil, günlük dildeki anlamıyla kullanılan "bilfiil yaşanan şey" anlamındaki tecrübeyi ifade etmiş olacağız.

Gazâlî’ye göre din, Tanrı'ya yapılan bir yolculuktur [سفر الى الله] Bu yolculuğun esasını, kalbin sıfatlarına ilişkin marifet oluşturur. Bu yolculuk vasıtasıyla kişi, dünyada iken Tanrı'ya ilişkin marifet ve ünsiyet kazanıp ahiret yolunu kavrar ve ahirette ebedi mutluluğu kazanır. ${ }^{10}$ Görüldügü gibi, Gazâlî için din, kişinin kendi hakikatini tanımasından başlayıp, Tanrı'yı tanımasına doğru devam eden ve sonunda ebedi mutluluğun kazanılmasına vesile olan bir yolculuk tecrübesidir.

Varlıklar konusuna gelince ise Gazâlî, tüm mevcudatı Tanrı ve O'nun fiillerinden ibaret olarak görür. ${ }^{11}$ Yani varlıklar kümesi, temelde Tanrı'nın zatı, zatıyla kaim sıfatları ve O'nun fillerinden meydana gelmiştir. Tanrı, varlık ismine layık olan yani gerçek manada var olan, varlığı kendinden olandır. Gerçek varlık O'dur ve O'nun dışındaki her şey, kendi nefsine bakan yönüyle yokluk, O'na bakan yönüyle varlık sayılır. ${ }^{12} 0$, mutlak kemâl sahibi olandır. Diğer varlıklar için ise O'na yakınlık dereceleri oranında kemâlden söz edilebilir. Tanrı'ya yakınlık-uzaklık, mekânsal değil, rütbe/derece itibariyledir. Varlıklar içerisinde en aşağı kısımda yani mutlak kemâlden en uzak noktada cisimler yer alır. ${ }^{13}$

Gazâlî, Tanrı'ya ilişkin bir takdis ve tenzih anlayışını eserlerinde sürekli gündemde tutar. Ona göre imanın ilk aşaması takdis yani mukaddes bir Tanrı anlayışıdır. ${ }^{14}$ Takdis, Tanrı'yı cisim olmaktan ve cisimlerde bulunan özelliklere sahip olmaktan tenzih etmektir. ${ }^{15}$ Söz gelimi, O'nun ilmini kişinin kendi ilmi gibi görmesi, O'nun kudretini kişinin kendi kudreti gibi görmesi, insanı tecsime düşürür. ${ }^{16}$ Tanrı için cismiyet muhaldir ve 0 , bundan

10 Ebû Hâmid Gazâlî, İhyâ-u Ulûmi'd-Dîn (Beyrut: Dâru İbn Hazm, 2005), 21-718-876; Ebû Hâmid Gazâlî, el-Erbaîn fi Usûlü'd-Dîn (Beyrut: Dâru'l-Minhâc, 2011), 104.

11 Ebû Hâmid Gazâlî, el-Maksadü'l-Esnâ fi Șerhi Esmâillâhi'l-Hüsnâ (Dımeşk: Matbaatu'sSabah, 1999), 41; Gazâlî, İhyâ, 891-1693-1811; Gazâlî, el-Erbaîn, 49; Ebû Hâmid Gazâlî, "İlcâmü'l-Avâm an İlmi'l-Kelâm", içinde Mecmûatü Resâili'l-İmami'l-Gazâlî (Kahire: elMektebetü't-Tevfikklyye, ty.), 337.

12 Ebû Hâmid Gazâlî, "Mişkâtü'l-Envâr", içinde Mecmûatü Resâili'l-Imami'l-Gazâlî (Kahire: el-Mektebetü't-Tevfîkıyye, ty.), 293-94; Gazâlî, el-Maksadü'l-Esnâ, 44-45.

13 Gazâlî, el-Maksadü'l-Esnâ, 31.

14 Gazâlî, İhyâ, 1423.

15 Gazâlî, "İlcâm", 320

16 Ebû Hâmid Gazâlî, "Mi'râcü’s-Sâlikîn”, içinde Mecmûatü Resâili'l-İmami'l-Gazâlî (Kahire: el-Mektebetü't-Tevfîkıyye, ty.), 55. 
münezzehtir. ${ }^{17}$ İnsanlar Tanrı'yı tanımak için kendi sıfatlarından yola çıkarlar ve kendi kemâl niteliklerini Tanrı'ya atfederken, noksan niteliklerini O'ndan tenzih ederler. Hâlbuki Tanrı, her iki nitelemeden de münezzehtir. 0 , yaratılmışlar için tasavvur edilen tüm sıfatlardan ve bu sıfatların benzerlerinden de münezzeh ve mukaddestir.18 Dolayısıla zat ve sıfatlarının hakikati itibariyle Tanrı yaratılmışlara benzemekten ve onlar tarafından ihata edilmekten münezzehtir.

Tanrı'ya ilişkin bu güçlü tenzih vurgusuyla birlikte Gazâlî, " $O$, kula her şeyden daha yakındır" şeklindeki bir açıklamayı yapmayı da ihmal etmez. Tanrı'nın insana ne kadar yakın olduğunu söylerken bile, bu yakınlı̆̆ın cisimlerin yakınlığına benzemediğini de tekrar hatırlatır. ${ }^{19}$ Gazâlî, Tanrı'yı bu kadar takdis ve tenzih ederken, O'nu büsbütün âlemden ve insandan uzaklaştırmaz. Tecrübe sinırlarımız içerisine giren eşyadan münezzeh ve aşkın olmakla birlikte Tanrı, varlıkların en zahiridir. ${ }^{20} 0$, cismani olmaktan münezzeh bir yakınlık ile kullarına her şeyden çok daha yakın olandır.

Gazali, Tanrı'nın fiillerinden ibaret gördüğü âlemi ikiye ayırır ve şöyle bir açıklama yapar: "Âlemler, kendi nefisleri bakımından cismanî-ruhanî; gözün idraki bakımından hissî-aklî; birbirlerine nispetle de ulvî-süflîdir. Ayrıca birincisine mülk ve şehadet, ikincisine gayb ve melekût âlemleri de denir." 21 Ona göre, melekût âlemine nispetle şehadet âlemi, öze nispetle kabuk, ruha nispetle beden, nura nispetle zulmet, yükseğe nispetle aşağı gibidir. Bundan dolayı o, melekût âlemine 'ulvî, ruhanî, nuranî âlem', şehadet âlemine ise 'süflî, cismanî, zulmanî âlem' isimlerinin verilebileceğini söyler. ${ }^{22}$ Bu ikili ayrımda, birinci sıradakiler duyuları aşan âlemi, ikinci sıradakiler ise duyularla algılanan yani hayvanlar ile insanların idrakte müşterek oldukları âlemi ifade etmektedir.

Gazâlî, duyular âlemi ile duyuları aşan âlem arasında bir benzerlik olduğunu kabul eder ve bu benzerliği açıklamak için, ayna, merdiven ve yazı örneklerini kullanır. $\mathrm{O}$, Ihyâ adlı eserinde, "dünya ahiretin aynasıdır" der. Bu görüşünü açıklarken de dünyanın şehadet âleminden, ahiretin ise gayb âleminden ibaret olduğunu belirtir. Aynadaki suretin, kendisine bakan kişinin suretine tabi olması gibi, şehadet âlemi de gayb âlemine tabidir. Her iki âlem arasındaki benzerliğin ortaya konması açısından ayna örneği yeteri

17 Gazâlî, "İlcâm", 321.

18 Gazâlî, el-Maksadü'l-Esnâ, 51-52.

19 Gazâlî, el-Erbaîn, 40-41.

20 Gazâlî, İhyâ, 1685.

21 Gazâlî, "Mişkâtü'l-Envâr", 298-99.

22 A.g.e., 291. 
Abdullah AKGÜL

kadar açı olmakla birlikte Gazâlî, aynaya ilişkin başka bir niteliğe daha dikkat çekerek; "aynadaki suret, vücut mertebesi olarak ikinci sirada yer alsa da görülme bakımından ilk sırada yer alır" der. Diğer bir ifadeyle kendisini görmek isteyen kişi, önce aynadaki suretini görür, daha sonra benzetme yoluyla kendi suretine ilişkin bir marifet edinir. Aynı şekilde mülk/șehadet âlemi, gayb/melekût âleminin bir benzeridir. ${ }^{23}$ Melekût âlemi varlık mertebesinde önce olup şehadet âlemi onun yansıması olarak sonra gelse de melekût âlemine ilişkin marifet söz konusu olduğunda, şehadet âlemi önce gelmektedir. Dolayısıyla melekût âlemine ilişkin marifetler şehadet âlemine ilişkin tecrübelerden yola çıkılarak elde edilir.

İki farklı seviyeyi birleştiren, aşağıda olan ile yukarıda olan arasındaki bağlantıyı sağlayan merdiven gibi, âlem de Tanrı ile insan arasındaki bağlantıyı sağlayan bir vasıtadır. "Hissî âlem, aklî âleme bir merdivendir"

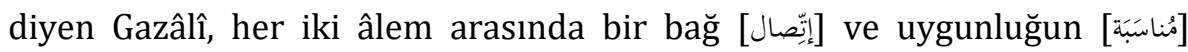
bulunmaması halinde, aklî âleme yükselme yolunun kapanmış olacağı kanaatindedir. Bu yolun kapalı olması ise Tanrı'ya yaklaşmayı imkânsız kllacaktır. ${ }^{24}$

Başka bir yerde de Gazâlî, âlemi akıllı kimselerin kendi dereceleri oranında okuyabildiği, Tanrısal manalar içeren bir yazıya benzetir. Bu yazıyı okumayı da "her şeyi, konulduğu hikmet üzere anlamak" şeklinde açıklar. ${ }^{25}$ Kâtibin yazdığı bir kelimeyi gören kişide, o kâtibin, âlim, kâdir, işiten ve gören sıfatlarına sahip olduğuna ilişkin yakinî bilgi hâsıl olur. Yazılmış bir kelimenin yazarın sıfatlarına şahitlik etmesi gibi, âlem ve içindekiler, kendisini takdir ve tahsis etmiş bir düzenleyiciye şahitlik ederler. ${ }^{26}$ İçerisindeki sebepleriyle birlikte dünya, kendisi vasıtasıyla Tanrı'ya ulaşılsın diye [ؤصول] yaratılmıştır ve ona bu amaçla yaklaşıılması gerekir.27

Gazâlî̀nin insan anlayışına gelince o, âlem için yaptığı ikili ayrımın bir benzerini insan için de yapar ve onun ruh ve bedenden yaratılmış olduğunu kabul eder. Diğer bir ifadeyle insanı, melekî ve hayvanî niteliklerden müteşekkil görür. ${ }^{28}$ Gazâlî, burada ruh ile beșerî ruhu kasteder. Bu ruh, Tanrı tarafından üflenmiş, ilim sahibi olabilen, dinen mükellef sayılan, insanın kendi hakikatini oluşturan kısmıdır. İnsan bedeninin canlılığını sağlayan, his

${ }^{23}$ Gazâlî, İhyâ, 1445

24 Gazâlî, "Mișkâtü'l-Envâr", 298-99.

25 Gazâlî, "Mi'râcü's-Sâlikîn", 54.

26 Gazâlî, el-Maksadü'l-Esnâ, 114.

27 Gazâlî, İhyâ, 1432.

28 Gazâlî, Kimyâ, 18. 
ve hareketin, şehvet ve gazabın kaynağı olan şey ise hayvanî ruhtur. Hayvanî ruhun ölmesi, bedenin ölmesi demektir. ${ }^{29}$

İnsanın hakikati olarak gördüğü beşerî ruh için Gazâlî, kalp, ruh, nefis, akıl kelimelerinin kullanılabileceğini, bir açıdan hepsinin aynı anlama referansta bulunduğunu kabul eder. ${ }^{30}$ Beden, bu ruhun mekânı değildir çünkü bu ruh bedene hulûl etmez; ona bitişik, ya da ondan ayrı değildir. Bedene yönelmiş, ona fayda ve feyz verir. ${ }^{31} 0$, kendi nefsiyle kaim, bir mahalde olmayan ve hiçbir şeye hulûl etmeyen bir cevherdir. Tanrı onu kendisine izafe etmiștir. ${ }^{32}$ Ruh ve kalp de bozulmaz, yok olmaz, ölmez. Bedenin fesadıyla ondan ayrılır. Bölünmez bir cevher olan ruh, kâmildir, bizatihi diridir, aynı zamanda dinin selameti de fesadı da ondan doğar. İnsana has olan ruh ölmez, sadece hal değiştirir. Bedenin ölmesiyle birlikte, bir menzilden diğer menzile geçmiş olur. İdrak eder, aydınlatıcıdır, faildir, hareket ettiricidir, aletleri ve cisimleri tamamlayıcıdır. ${ }^{33}$ Emr-i rabbanî olması ve ilahi işlerle [الأمور الإلهية] münasebeti olan gizli bir sırra sahip olması dolayısıyla, insana Tanrısal sıfatlar sevimli gelir ve hatta insana en çok haz veren şeyler bunlardır. İnsan bu yüzden, kemâli arzular. Tanrı'ya yaklaşmak için hakiki kemâl arzusu gerekli olmakla birlikte, insanların çoğu bu kemâli mal ve makam kudretinde ararlar. ${ }^{34}$

Gazâlî, insanın tamamının âlemlere ve onların parçalarına uyumlu olduğunu düşünür. Ona göre insan, ruhuyla yüce âleme; su, hava, ısı ve topraktan meydana gelen unsurlarıyla yeryüzünün cevherlerine; hayvanî ruhu ile hayvanlara; vücut yapısında, mevcut damarlarla ve gidalanıp büyümesiyle bitkilere; kemikleriyle de cansız varlıklara [مادات] benzer. Bunu küllî bir benzeyiş olarak kabul eden Gazâlî; "eğer insan vücudunun parçaları âlemin her bir parçası ile karşılaştırılsa, aralarında bir benzerlik olduğu görülür" der. ${ }^{35}$ İnsanî suretin hem yaratana, hem de âlemdeki harikalara delalet ettiğini savunan Gazâlî; "Âlemde hiçbir garip ve müşkül iş yoktur ki, insanda onun ilminin anahtarı bulunmasın" der. ${ }^{36}$ Ona göre mevcudat idrak edilirken, varlık önce histen hayale, oradan da kalbe aktarılır. Kişiye bu

\footnotetext{
${ }^{29}$ Ebû Hâmid Gazâlî, “er-Risâletü'l-Ledünniyye”, içinde Mecmûatü Resâili'l-İmami'l-Gazâlî (Kahire: el-Mektebetü't-Tevfîklyye, ty.), 242.

30 Gazâlî, İhyâ, 877-79.

31 Gazâlî, “er-Risâletü’l-Ledünniyye”, 243.

32 Gazâlî, "Mi'râcü's-Sâlikîn", 55-56.

33 Gazâlî, “er-Risâletü'l-Ledünniyye”, 241-43; Gazâlî, el-Erbaîn, 311.

34 Gazâlî, el-Erbaîn, 174-76.

35 Gazâlî, "Mi'râcü's-Sâlikîn", 58.

36 A.g.e., 60.
} 
Abdullah AKGÜL

şekilde ulaşmayan bir şey asla idrak edilemez. Şayet âlemin tümü için insanın kendisinde birer misal bulunmazsa, insan onun hakkında bir malumat da edinemez. ${ }^{37}$ İlahi hikmetin insanı her şeyi toplamış [جامع] bir defter kılmasının faydasını gayb için anahtar olması açısından değerlendiren Gazâlîye göre insan, kendisinde şahit olduğu şeyleri müşahede edemediği şeylere delil getirir. İlahi hikmet de gaibi şahide kıyas yapıp tümevarım ve temsil yoluyla delil getirebilsin diye insanî suretleri âlemlerin harikaları [غجائب] ve şaşllacak şeylerine [غرائب] benzer tahsis etmiştir. ${ }^{38}$ İnsanın hacminin küçüklüğüne rağmen, neredeyse bütün âlemin harikalarını kendi şahsında toplamasını Tanrı'nın kullarına rahmeti olarak açıklayan Gazâlî, üzerinde düşünüldügü takdirde, insanoğlunun âlemin bir özeti şeklinde yaratılmış olmasının Tanrı'yı bilmeye vasıta olabileceği kanaatindedir. ${ }^{39}$

Sonuç olarak, varlıklar kümesi, Tanrı'nın zatı ve fiillerinden meydana gelir. Tanrı, kendi zatı ve zatıyla kaim sıfatlarıyla, yaratılmışlara benzemekten münezzehtir ve 0 , hakikatine kendisi dışındakilerin ulaşılamayacağı bir varlıktır. Tanrı dışındaki tüm varlıklar, O’nun fiilleridir ve âlem olarak isimlendirilir. Bu âlemin tamamından örnekler taşıyan, onun bir özeti mesabesinde olan varlık ise insandır. İnsanın âlemin tamamından örnekler taşıması, onun öncelikle âlemi tanımasını ve oradan da Tanrı'yı tanımasını sağlar.

\section{B. Dinî Tecrübenin Mahiyeti}

Tecrübe konusunu ele alırken, varoluşun tüm boyutlarını kapsayan bütüncül bir insan tecrübesini göz ardı edip, ona parçacı yaklaşmanın problemli olduğu kanaatimizi öncelikle vurgulayarak; Gazâlînnin fikirleri doğrultusunda, dine nispet edilebilecek tecrübelerin mahiyetini sorgulayalım.

Daha önce de ifade ettiğimiz gibi din, kişinin kendisini tanımasından başlayıp, Tanrı'yı tanımasına doğru devam eden ve kişiye ebedi mutluluğu kazandıracak olan bir yolculuktur. Yolculuk fenomeni kendi içerisinde; ulaşılması arzulanan bir hedefi, bu hedefe ulaştıracak bir yolu, bu yolda ilerleyecek bir yolcuyu ve bu yolcunun uygulayacağı bir metodu barındırır. Bu kemâl yolculuğunda ulaşılması arzulanan hedef Tanrı; kendisi vasıtasıyla Tanrı'ya ulaşılabilecek yol âlem; bu yolda ilerleyecek olan yolcu insan ve bu yolun metodu mücahededir. Ontolojik arka planı itibariyle, Tanrı'dan

37 Gazâlî, İhyâ, 897.

38 Gazâlî, "Mi'râcü's-Sâlikîn”, 54-55.

39 Ebû Hâmid Gazâlî, Mîzânü'l-Amel (Kahire: Dâru'l-Meârif, 1964), 200. 
başlayarak gelen ve insanda özetini bulan varlık silsilesine karşılık; bu yolculuk, insandan Tanrı'yadır.

Gazâlî̀ye göre, insan doğumundan itibaren bir gelişim süreci içerisine girer. Onun, önce duyuları, sonra temyiz kuvveti ve en sonunda aklî melekeleri gelişir. ${ }^{40}$ Akıl nuru diye isimlendirilebilecek olan bu melekelerin henüz ortaya çıkmadığı çocukluk yıllarında, insanın kalbinde şehvet ve gazabın hâkimiyeti söz konusudur. İdrakin sadece duyulardan ibaret olduğu bu yıllarda, insanın hayvanî ruh tarafı etkindir. Şöyle ki, hayvanların hareketlerini belirleyen iki temel unsur olan şehvet ve gazap, bu yıllarda çocuğun da hareketlerini belirleyen temel unsurlardır. Daha sonra akıl nuru ortaya çıkar ve kırk yaşına kadar gelişim ve artış gösterir. Bu nur ile birlikte şehvet ve gazaba galebe çalındığı takdirde, insanın meleklik tarafı ağır basacak yani artık hareketlerini belirleyen aklı olacaktır. ${ }^{41}$ Tabii ki bunun sağlanması kolay bir şey değildir. Daha önce kalbi ele geçirmiş olan şehvet ve gazap ile akıl nurunun çatışması, kalbin bir savaş meydanına dönmesine sebep olur. ${ }^{42}$ Gazâlî bu durumu, Tanrı'nın orduları ile şeytanın ordularının savaşı olarak açıklar. ${ }^{43} \mathrm{O}$, farklı yerlerde farklı isimler saysa da başta şehvet ve gazabı, bunlarla birlikte nefsi, diğer bir ifadeyle hayvanî ruhu ve hizmetçilerini, şeytanın orduları olarak kabul eder. Bunların karşısında da aklı ve bazı yerlerde ise hayrı ilham eden meleği, Tanrı'nın taifesi ya da meleklerin orduları olarak tanımlar. ${ }^{44}$ Mesele, gazap ve şehvet kuvvetine karşı, akıl kuvvetini galip kılmaktır ${ }^{45}$ ve bu savaş kişi ölünceye kadar devam eder. ${ }^{46}$ Mücadelede galip olan taraf kalbin hâkimiyetini elde etmiş olur ve kalp bazen meleklerin bazen de şeytanın mekânı haline gelir. ${ }^{47}$ Diğer bir ifadeyle, kişiye bazen beşerî ruh, bazen de hayvanî ruh hâkim olur. Bu içsel çatışma hali, ölünceye kadar bireyde varlığını hissettiren varoluşsal bir gerilimi ifade eder. Bu gerilim, tıpkı iple ağaca bağlanmış ve havada asılı duran bir insanın yaşadığı gerilim gibidir. Şöyle ki, onu aşağı çeken bir güç ve yukarıda tutmaya çalışan başka bir güç vardır ve o bu ikisi arasında acı duyar haldedir. Zıtlıkları kendi içinde barındıran yani beşerî ruh ve hayvanî ruhtan

40 Ebû Hâmid Gazâlî, “el-Munkızu mine'd-Dalâl”, içinde Mecmûatü Resâili'l-İmami'l-Gazâlî (Kahire: el-Mektebetü't-Tevfîkıyye, ty.), 598-99.

41 Gazâlî, el-Erbaîn, 226; Gazâlî, el-Maksadü'l-Esnâ, 32.

42 Gazâlî, el-Erbaîn, 226-27.

43 A.g.e., 249.

${ }^{44}$ Ebû Hâmid Gazâlî, "Ravzatü't-Tâlibîn ve Umdetü’s-Sâlikîn”, içinde Mecmûatü Resâili'lİmami'l-Gazâlî (Kahire: el-Mektebetü't-Tevfîkıyye, ty.), 162.

45 Gazâlî, el-Maksadü'l-Esnâ, 125.

46 Gazâlî, İhyâ, 908.

47 A.g.e., 904. 
Abdullah AKGÜL

müteşekkil olan insan da ölünceye kadar, içsel olarak bu gerilimi ve bu acıyı duymaya devam eder. ${ }^{48}$

Buluğ çağına gelip de akıl nurunun parlamasıyla birlikte başlayan bu varoluşsal gerilim ve acı dolayısıyla insanın hayatı boyunca en çok ihtiyaç duyduğu şey mutluluktur. İnsan sürekli mutluluğu arar ve onun en büyük gayesi budur. ${ }^{49}$ İnsan mutluluğu farklı şeylerde arasa da onu tatmin edecek hakiki mutluluk, bu dünya ile mukayyet olmayıp, mutlak olan uhrevî mutluluktur. ${ }^{50}$ Kişi, imanı ve bu iman sonucu edineceği marifeti oranında mutluluğu elde eder. ${ }^{51}$ İman aslında marifetullah yani Tanrı'yı tanımaktır. ${ }^{52}$ En büyük mutluluk Tanrı'ya kavuşmak; en büyük mutsuzluk ise O'ndan mahrum kalmaktır. ${ }^{53}$ Dolayısıyla Gazâlî, insanın en büyük amacı dediği mutluluğu, Tanrı'yı tanımaya bağlar. Tanrı'yı tanımak, âlemin yaratılması, peygamberlerin gönderilmesindeki ana hedef ${ }^{54}$ ve aynı zamanda insan için fıtrî bir ihtiyaçtır. Bu ihtiyacın karşılanması, kişinin sağlıklı olması demektir. ${ }^{55}$ Tanrı'yı tanımak, kalbin sağlıklı hali iken, O'nu tanımamak, kalp için öldürücü bir zehirdir. ${ }^{56}$ Aynı zamanda Tanrı'yı tanımak, kalp için gıda57 ve ışık mesabesindedir. ${ }^{58}$ İnsanı diğer yaratılmışlardan üstün kılan şey olan marifet, ${ }^{59}$ kişinin kurtuluş ve mutluluğu için gereklidir. 0 , taklit yoluyla edinilebilecek herhangi bir bilgi değil, bizzat tecrübe edilerek kazanılan bir bilgidir. ${ }^{60}$ Herhangi bir bilgi, ateşi görmek ise; marifet, ateşe dokunmak mesabesindedir. Sadece parmağın ateşe dokunmasıyla tüm vücudun etkilenmesi gibi, marifetin kalbi sarmasıyla da tüm organlar bundan etkilenir. ${ }^{61}$ Dolayısıyla marifet, ilimlerin en şereflisidir ve insanın kemâl ve mutluluğu ancak Tanrı'ya ilişkin marifet edinmesiyle sağlanabilir. ${ }^{62}$

İnsanın ebedi mutluluğunu sağlayacak olan marifeti, diğer bir ifadeyle zaman ve mekândan münezzeh bir Tanrı'ya yapılacak yolculuğu nasıl

48 Gazâlî, el-Erbaîn, 329.

49 Gazâlî, "Mi'râcü's-Sâlikîn", 95.

50 Gazâlî, Mîzân, 304-5.

51 Gazâlî, el-Erbaîn, 53.

52 Gazâlî, İhyâ, 1678.

53 A.g.e., 1508.

54 Gazâlî, "Ravzatü't-Tâlibîn", 158.

55 Gazâlî, Ihyô, 945.

56 Gazâlî, "el-Munkız", 601.

57 Gazâlî, el-Erbaîn, 292-93.

58 Gazâlî, “Ravzatü’t-Tâlibîn”, 120-21.

59 Gazâlî, Ihyâ, 876.

${ }^{60}$ Ebû Hâmid Gazâlî, el-Keșf ve't-Tebyîn -Esnâfu'l-Mağrûrîn (Kahire: Mektebetü’l-Kur'an, ty.), 463.

61 Gazâlî, “Ravzatü't-Tâlibîn”, 120.

62 Gazâlî, Ihyyâ, 884. 
anlamak gerekir? "Tanrı́ya yakınlık, mekân olarak değil kemâl olaraktır" derken Gazâlî, bu durumu öğrencinin hocasını çok sevip, kemâl olarak ona benzeme isteğiyle açıllar. Şöyle ki, öğrencinin kemâli ilimle uğraşmasıyladır ve ilim bir defada değil, yavaş yavaş elde edilir. Bunun gibi, Tanrı'ya kemâl yönüyle yakınlaşmak, insanın aşağıların en aşağısından yücelere doğru bir yolculuğa çıkması demektir.63 Başka bir yerde de "mekân yönünden değil de sıfatyönünden Hakk'a yaklaşmak"64 tabirini kullanan Gazâlî'ye göre buradaki yolculuktan kastın maddî bir yolculuk olmadığı ve kendisi cisim olmayan Tanrı'ya cisimsel bir yaklaşmanın muhal olduğu açıktır. Ayrıca Tanrı'ya yaklaşmak, insanın kendi kemâlini sağlamasıyla mümkündür. Kulun kemâli ve mutluluğu da Tanrı'nın ahlakıyla ahlaklanması ve mümkün olduğu ölçüde O'nun isimleri ve sıfatlarının manalarıyla süslenmesi yoluyladır. ${ }^{65}$

Gazâlî, insanın kemâl yolculuğunu, şehadet âleminden gayb âlemine bir yolculuk olarak da kabul eder. "İnsan olmanın özelliği, şehadet âleminden melekût âlemine yolculuk yapmaktır" diyen Gazâlî, daha aşağı seviyede olduğunu kabul ettiği şehadet âleminde kalıp da bu yolculuğu gerçekleştirmemeyi hayvanlarla eşit olmaya benzetir. Hatta ona göre hayvanların buraya yükselecek kanatları olmadığı yani fitratlarında böyle bir özellik bulunmadığı için, bir insanın şehadet âleminde kalmayı yeğlemesi aslında hayvanlardan aşağı olması demektir. ${ }^{66}$ Dolayısıyla hayvanlarla ortak olduğumuz duyular âleminden duyular üstü âleme olduğu anlaşılan bu yolculuğun diğer bir boyutunun da beden ve ruhtan müteșekkil insanın, kendi bedeninden ruhuna, diğer bir ifadeyle kendisinden yine kendisine yaptığı bir yolculuk olduğu da söylenebilir. Gazâlî”nin “insaniyet âlemine yükselmek"67 dediği bu yolculuğa koyulmak, insan olma yolunda ilerlemeyi ifade eder.

Bu yolculukta insanın önünü aydınlatacak, ona doğru yolu gösterecek olan şey vahiydir. Şeriatı bir bina, aklı da onun temeli kabul eden; şeriatı harici bir akıl, aklı da dâhili bir şeriat olarak tanımlayan ve "akıl göze, şeriat da ışığa benzer"68 diyen Gazâlîye göre insan aradığı hakikî mutluluğa vahyin ışığında ulaşabilir. Vahyin yol göstericiliğini kabul etmek için öncelikle kişinin iman etmiş olması gerektiği açıktır. Dinî tecrübenin başlangıç

63 Gazâlî, Mîzân, 403-4.

${ }^{64}$ Gazâlî, el-Maksadü'l-Esnâ, 30.

65 Gazâlî, "Ravzatü't-Tâlibîn", 137.

66 Gazâlî, "Mişkâtü'l-Envâr”, 291.

67 Gazâlî, el-Erbaîn, 320-21.

68 Ebû Hâmid Gazâlî, Meâricu'l-Kuds fî Medârici Ma'rifeti'n-Nefs (Beyrut: Dâru'l-Kütübi'lİlmiyye, 1988), 73. 
Abdullah AKGÜL

noktasının burası olduğu söylenebilir. Her ne kadar iman etmeden önce de kişinin tüm tecrübeleri Tanrı'nın fiilleri sahası içerisinde gerçekleşiyor olsa da iman etmesiyle birlikte bu tecrübeleri başka bir anlam boyutu kazanır. Söz gelimi Gazâlî̀ye göre eşyaya natüralist olarak yaklaşan kişilerin dalalet ve şekaveti artarken Tanrı'nın fiili olarak yaklaşan kişilerin hidayeti ve mutluluğu artar. 69

Vahyin ışığında gerçekleșen bu yolculukta insan basiret adı verilen bir göze sahip olur. Bu göz, insanın zahir gözünden farklı olarak gaybı idrak etme yetisidir. Tanrı bir kuluna hayır murat ettiği zaman zâhir gözünün göremediği şeyleri görebilmesi için o kişinin kalbini açar. ${ }^{70}$ Gazâlî̀nin, "göz için her şeyin görülebilir olması zâhir nurla olduğu gibi, batınî basiret için her şeyin zahir olması Tanrı iledir"71 sözüyle de basiret sahibi olmak için vahyin gerekliliğine vurgu yaptığı görülür. Şeytan ve meleğin etkisine açık olan kalbin bunlar arasında kararsız kalması ve doğru yolu bulamamasını Gazâlî, gece karanlığında çölde, birçok yolun ortasında kalmış, yolunu seçemeyen bir yolcu benzetmesiyle açıklar. Bu kişinin yolunu bulabilmesi için ancak basîret gözüne ve güneşin ışığına ihtiyacı vardır. "Basîret gözü, takva ile temizlenmiş kalp; güneş ise Allah'ın kitabı ve Rasulünün sünnetinden edinilen ilimdir."72 Tüm insanlar zâhir gözleriyle şehadet âlemine baktıkları halde, basiret sahipleri gördüklerinden farklı anlamlar çıkarırlar. Gazâlî bu durumu

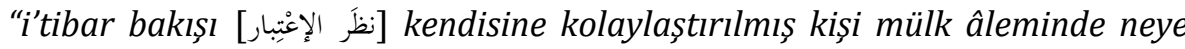
baksa onunla melekût âlemine geçer ve bu geçişine 'ibret' denir" șeklinde açıklar. Ona göre basîreti kör olanlar bu geçişi gerçekleştiremeyip mülk/şehadet âleminde tıkanır kalırlar. Bu durum onlar için cehennem ateşi olur da onun acısını ancak perdelerin kalktığı an olan ölümle birlikte duyarlar. ${ }^{73}$

Vahiy ışığında ve basiret gözüyle gerçekleştirilen bu yolculukta, insanın gayretiyle ulaşabileceği yolun başlangıcı ve anahtarı Tanrı'nın zikrine gark olmak ve kalbi O'nun dişındakilerden temizlemek; sonu ise Tanrı'da fani olmaktır. İnsanın ihtiyarı ve kesbiyle elde edebileceği kısım buraya kadardır. Ancak, Tanrı'da fani olmak, bunun ötesinde yașanacaklara nispetle yolun başlangıcı sayılır. Önceki yaşananların hepsi yola giriş koridoru mesabesindedir. ${ }^{74}$ Dolayısıyla Tanrı'da fani olmak, kemâl

${ }^{69}$ Gazâlî, İhyâ, 1824.

70 Gazâlî, "er-Risâletü'l-Ledünniyye”, 243.

71 Gazâlî, "Mişkâtü'l-Envâr", 297.

72 Gazâlî, İhyâ, 908.

73 A.g.e., 1445.

${ }^{74}$ Gazâlî, "el-Munkız", 597. 
yolculuğunda insanın gayretiyle ulaşabileceği en yüksek mertebeyken bunun ötesinde ulaşılabilecek daha birçok mertebenin varlığı da anlaşılmaktadır. Gazâlî, bundan ötesini sözlerle ifade etmeye çalışmanın hatalar içereceği ve yanlış anlaşılmalara sebep olacağı kanaatindedir ${ }^{75}$ ve bu konuda fazla bir şey söylemez.

Bu yolculukta insanların sıra dışı tecrübeler yaşaması hakkında neler söylenebilir? Burada öncelikle, yolculuk fenomeninin kendi içinde sürekli yeni tecrübelere açıklığı barındırdığını ve yolculuğa çıkmanın bizzat kendisinin, yolculuğa çıkmamaya göre sıra dışı bir şey olduğunu söylemek gerekir. ${ }^{76}$ Yola koyulup da kendisine marifet kapıları açılmaya başlayan kişilerden bahsederken Gazâlî, bu kişilerden bazılarının marifetin başlangıç noktalarından bir koku alınca şaşkınlığa düşerek bunlarla sevinip garipliklerine hayran olduklarını, böylece maksada ulaşmaktan mahrum kaldıklarını belirtir. Bunun bir aldanma olduğunu ve Tanrı yolunun acayipliklerinin nihayetinin olmadığını söyleyerek bu durumdakileri, sultanın yanına gitmek için yola çıkıp meydan kapısının önündeki bahçenin çiçek ve ışıklarına takılıp görüşme saatini kaçıran kişilere benzetir. ${ }^{77}$ Kemâl yolculuğunda olan insan için yaşadığı her yeni tecrübe, kendisinin bir önceki haline göre sıra dışı gelebilir. Bu yolculuk zaten acayipliklerle doludur. Kişiye düșen görev, bunlara takılmadan yolculuğuna devam etmesidir. Dolayısıyla kemal yolculuğunda insanın, sıra dışı şeyler tecrübe etmesi normal karşılanırken bunlara takılıp kalması doğru karşılanmaz.

İnsanın ilerleme kaydettiği bu kemâl yolculuğunda yaşadığı her şeyi başkalarına aktarabilmesi mümkün müdür? İlgili yolculuğu sûfîler üzerinden betimlerken Gazâlî, onların bu yolun başından itibaren müşahede ve mükaşefeler yaşadıklarını belirtir. Sonra kişinin hali, suret ve misalleri müşahededen sözle ifade edilemeyecek derecelere yükselir. Bu halini ifade etmeye çalışan kişinin sözleriyse kaçınılması mümkün olmayan apaçık hatalar içerecektir. ${ }^{78}$ Bazı ilimler vardı ki, sadece riyazetle onlara ulaşılabilir. $\mathrm{Bu}$ ilimler kitaplarda yazllamaz ve bu konuda herhangi bir nimete erişememiş olanlara onlardan bahsedilemez. Bu ilimler sadece ehliyle paylaşılır. ${ }^{79}$ Demek ki bizzat tecrübe ederek edinilen bilgilerin bazı kısımları anlatılabilir fakat onu ehli olmayana anlatmak, karşıdaki insanın ya anlatılanları yanlış anlamasına ya da söyleyenin hatalı olduğunu düşünüp o

75 A.g.e., 597-98.

76 Gazâlî, Kimyâ, 90.

77 Gazâlî, el-Keșf ve't-Tebyîn, 477-78.

78 Gazâlî, "el-Munkız", 597-98.

${ }^{79}$ Gazâlî, İhyâ, 29. 
Abdullah AKGÜL

kişiye zarar vermesine sebep olabilir. Söz gelimi, bu ilimleri halka anlatmaya kalkışan kişinin sözleri halkın akıllarını aşar da onu deli ya da kâfir addederler. ${ }^{80}$ Gazâlî'nin bu konudaki yöntemi, insanlardan selamette olmak ve insanların kendisinden hakkıyla istifade edebilmelerini sağlamak için "karșıdakinin aklı miktarınca konuşmak"tır.81 Örneğin Gazâlî, insanın hakikati dediği ruhtan bahsetmez ve bu konuda Peygamberi örnek aldığını belirtir. ${ }^{82} 0$, "şeriat, insana mahsus olan ruhun hakikatinden bahsetmeye izin vermemiştir" der; çünkü herkes bunu kaldırabilecek durumda olmayabilir. "Mahiyetini bilmediğin, henüz ulaşmadığın bir hale ilişkin söylenecek bir söz vasitasiyla o hale ilişkin bir ilim elde etmen muhaldir" diyen Gazâlî sadece tatmakla ilgili olan şeyler hakkında sözle niteleme yapmanın uygun olmadığı kanaatindedir. 83 Buradan da anlaşıldığı gibi insanın kemâl yolculuğunda, sözle ifade edemeyeceği bazı tecrübeler yaşaması mümkün olmakla birlikte sözle ifade edebileceği fakat bilinçli olarak anlatmamayı tercih ettiği tecrübeler de vardır.

$\mathrm{Bu}$ kemâl yolculuğunda âleme ilişkin tecrübeler, Tanrısal ve dine ilişkin tecrübeler olarak kabul edilebilir mi? Gazâlî̀ye göre bu konudaki temel nokta, eşyaya Tanrı'nın fiili olarak bakıp-bakmamakla alakalıdır. Sözgelimi, O'nun fiili olarak bakılmadığı sürece, bedenin sırf tıbbî gayelerle incelenmesinde ya da kâinatın, yıldızlar hakkında hüküm çıkarmak amacıyla incelenmesinde hiçbir kıymet yoktur. ${ }^{84}$ Eşyaya ilişkin marifet aslında Tanrı'nın fiillerine ilişkin bir marifet olması hasebiyle şereflidir. Bu marifetle ya O'nun filleri bilinmiş olur ya O'na yaklaștıran yollar bilinmiş olur, ya da O'nun marifetine ulaşmayı kolaylaştıracak şeyler bilinmiş olur. Âleme ilişkin bunun dişındaki herhangi bir yaklaşımın ise değeri yoktur. ${ }^{85}$ Dolayısıyla Tanrı'nın marifetinden önceki her marifet, aslında O'nun marifetine bir basamaktır. ${ }^{86}$

İnsan, idrak yetilerinin elverdiği oranda âleme ilişkin birçok tecrübeler edinebilir. Tecrübe edilen ve edilemeyen kısımlarıyla âlemin tamamının Tanrı'nın fiili olduğu hesaba katıldığında, insanın tüm tecrübeleri Tanrı'nın fiilleri sahası içerisinde cereyan etmektedir. “Kim fiilleri, fiil olarak

${ }^{80}$ A.g.e., $1674-75$.

81 Gazâlî, Kimyâ, 72.

82 Ebû Hâmid Gazâlî, "Kânûnu't-Te'vîl", içinde Mecmûatü Resâili'l-İmami'l-Gazâlî (Kahire:

el-Mektebetü't-Tevfîklyye, ty.), 629.

83 Ebû Hâmid Gazâlî, "Eyyühe'l-Veled", içinde Mecmûatü Resâili'l-İmami'l-Gazâlî (Kahire:

el-Mektebetü't-Tevfîkıyye, ty.), 278.

|826| 84 Gazâlî, el-Erbaîn, 175-76.

85 Gazâlî, el-Maksadü'l-Esnâ, 69.

86 A.g.e., 113. 
bilirse, edineceği şey, faili bilmekten başka bir șey değildir"87 diyen Gazâlî̀ye göre şayet kişi, tecrübe ettiği şeyin bir şahsın fiili olduğu bilincindeyse, bu tecrübeden edineceği her bilginin aslında faile ilișkin bir bilgi olduğunun farkında olacaktır. Âleme, Tanrı'nın fiili olarak yaklaşan kişi, ona ilişkin her ne öğreniyorsa aslında onun faili olan Tanrı'ya ilişkin bir şeyler öğrendiğini bilir. Dolayısıyla, doğru bakış açısını barındırdığı takdirde, âleme ilişkin her tecrübe Tanrı'ya ulaştırıcıdır ve dinîdir.

Kemâl yolculuğu, mülk âleminden melekût âlemine yapılan bir yolculuk olduğuna göre, melekût âlemine ilişkin tecrübeler, Tanrı'nın zatına ilişkin tecrübeler sayılabilir mi? Gazâlî, ikili âlem ayrımında ayetlerde sıklıkla geçen "gökler ve yer" tabirini örnek gösterir. ${ }^{88}$ Burada dikkate değer olan husus, ayetlerde yerin tekil, göklerin ise çoğul kullanılıyor olmasıdır. Dolayısıyla, hayvanlardan farklı olarak melekût âlemine yolculuk yapabilen insan için, şehadet âlemini aşmak söz konusu olsa da burada, şehadet âlemini aşmanın, melekût âleminin tamamına ulaşmak anlamına gelmediğini vurgulamak gerekir. Bu ikili ayrım için; "burası ve orası" değil, "burası ve ötesi" tabiri durumu daha iyi açıklayacaktır. Ayrıca şunu da belirtmek gerekir ki; mülk de melekût da Tanrı'nın fiili olan âleme ilişkin bir sınıflandırmadır ve mülk âleminde de melekût âleminde de yaşanan her tecrübe sonuç itibariyle Tanrı'nın fiilleri sahası içerisinde gerçekleşmektedir ve Tanrı'nın zatı tecrübe edilemez.

$\mathrm{Bu}$ yolculukta ulaşılması arzulanan hedef Tanrı'dır. Daha önce de ifade ettiğimiz gibi 0 , zatı itibariyle biricik varlıktır ve 0'nun dışındaki hiçbir varlık ne bilgi ne de tecrübesiyle O'nu ihata edemez. Bu durumda, insanın kemâl yolculuğu için nihai bir nokta takdir edilebilir mi? Âlemin Tanrı'ya ulaşmak için bir araç kılınmış olduğunu kabul eden Gazâlî, Tanrı'ya ulaşmayı marifet ile ilişkilendirir. ${ }^{89}$ Yani Tanrı'ya yolculuk, O'nun hakkında marifet sahibi olmak yoluyladır. İnsanın yolculuğu, âlemden marifetler edinmek suretiyle Tanrı'ya ulaşmaya çalışmaktır. Gazâlî, marifet edinmek konusunda, biri yetersiz [قاصِ], diğeri ise kapalı [مسدود] olarak nitelendirdiği iki yoldan bahseder. Birincisi, insanın bildiği şeylere benzetme yoluyla Tanrı'nın isim ve sıfatlarından bahsedilmesidir. Söz gelimi, bilen, gücü yeten, hayat sahibi ve konuşan oluşumuzu kendimizden yola çıkarak bilir, sonra Tanrı için de aynı sıfatların olduğunu vahiy ya da delil ile öğreniriz. Söz gelimi, kulakları

87 Gazâlî, Ihyyâ, 753.

88 Gazâlî, "Mișkâtü'l-Envâr", 291.

${ }^{89}$ Ebû Hâmid Gazâlî, "Minhâcü'l-Ârifîn", içinde Mecmûatü Resâili'l-İmami'l-Gazâlî (Kahire: el-Mektebetü't-Tevfîkıyye, ty.), 229. 
Abdullah AKGÜL

duymayan birisinin Tanrı'nın işiten olduğunu kavrayamaması gibi insan kendisinde münasebetini kuramadığı şeyleri de kavrayamaz. Gerçekte bir şeye, kendisine benzemeyen başka bir şey ile benzetme yapmak vehim oluşturmaktan öteye gitmez. Dolayısıyla, bizim kendimizden bildiğimiz sıfatlarımız ile Tanrı'nın sıfatları birbiriyle tamamen örtüşemez çünkü hiçbir şey O'nun misli değildir. Marifetin kapalı olan ikinci yoluna gelince bu da kulun, rububiyyet sıfatlarının tümünü elde edip rab oluncaya kadar beklemesi ve bizzat rab olmayı tecrübe ederek bilmesidir. Tanrısal sıfatlara Tanrı'nın kendisinden başkasının sahip olması ise imkânsızdır. Hakiki marifetin yolu bu olduğu halde, bu yol Tanrı'dan başkasına kapalıdır. Dolayısıyla, Tanrı'ya ilişkin hakiki marifet kendisi dışındakiler için mümkün değildir. ${ }^{90} \mathrm{Bu}$ da bize, bu yolculukta elde edilecek marifetlerin bir sınırının olmadığı ve bundan dolayı da bu yolculuğun bir sonunun olmadığını gösterir.

\section{Sonuç}

Sonuç olarak, Gazâlî'nin fikirleri üzerinden bir dinî tecrübe tanımı yapacak olursak şunları söyleyebiliriz: Din, Tanrı'ya yapılan bir yolculuktur ve dinî tecrübe de Tanrı'ya yolculuk tecrübesidir. O'na yolculuk yapmak, O'na yakınlaşmak demektir ve bu yakınlaşma, mekân olarak değil, kemâl olarak gerçekleşir.

İnsanın kemâli, mutlak kemâl sahibi olan Tanrı'nın sıfatlarıyla sıfatlanması yoluyladır. İlgili sıfatlar, insanın kendi özünde mevcuttur. Kişiye düşen, kendisinde bilkuvve olan bu sıfatları bilfiil hale getirmek için çaba harcamak yani bir yolculuğa çlkmaktır. Bu yolculuk sayesinde kişi, kendi varoluşsal ihtiyacı olan ve içsel olarak sürekli aradığı gerçek mutluluğu elde eder. Mutluluk gibi varoluşsal bir ihtiyacı gidermesi bakımından bu yolculuk da insan için varoluşsal bir ihtiyaçtır. İman etmekle başlayan ve sonu olmayan bu kemâl yolculuğunda, mutlak kâmil olmak, marifetin nihai derecesine ulaşıp Tanrı'nın zatının hakikatini ihata etmek mümkün değildir çünkü mutlak kemâl Tanrı'ya aittir. Özetle, dinî tecrübe, insanın kemâl yolculuğudur ve bu yolculuğa insan olma yolculuğu da denebilir.

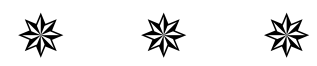

KAYNAKÇA

AKGÜL, Abdullah. "Terim Olarak Dinî Tecrübe: Tarihsel Bir İnceleme". Social Sciences Studies Journal 4, sy 21 (2018): 3584-3590. doi:10.26449/sssj.778.

${ }^{90}$ Gazâlî, el-Maksadü'l-Esnâ, 35-37. 
GAZÂLî. el-Erbaîn fi Usûlü'd-Dîn. Beyrut: Dâru'l-Minhâc, 2011.

GAZÂLÎ. el-Keșf ve't-Tebyîn -Esnâfu'l-Mağrûrîn. Kahire: Mektebetü'l-Kur'an, ty.

GAZÂLÎ. el-Maksadü'l-Esnâ fî Şerhi Esmâillâhi'l-Hüsnâ. Dımeşk: Matbaatu'sSabah, 1999.

GAZÂLÎ. "el-Munkızu mine'd-Dalâl”. Içinde Mecmûatü Resâili'l-Imami'lGazâlî, 578-608. Kahire: el-Mektebetü't-Tevfîkıyye, ty.

GAZÂLî. "er-Risâletü'l-Ledünniyye”. Içinde Mecmûatü Resâili'l-Imami'lGazâlî, 239-53. Kahire: el-Mektebetü't-Tevfîkıyye, ty.

GAZÂLÎ. “Eyyühe'l-Veled”. Içinde Mecmûatü Resâili'l-İmami'l-Gazâlî, 274-86. Kahire: el-Mektebetü't-Tevfîkıyye, ty.

GAZÂLÎ. İhyâ-u Ulûmi'd-Dîn. Beyrut: Dâru İbn Hazm, 2005.

GAZÂLÎ. “İlcâmü'l-Avâm an İlmi'l-Kelâm”. Içinde Mecmûatü Resâili'l-İmami'lGazâlî, 319-55. Kahire: el-Mektebetü't-Tevfîkıyye, ty.

GAZÂLÎ. “Kânûnu't-Te'vîl”. Içinde Mecmûatü Resâili'l-İmami'l-Gazâlî, 623-30. Kahire: el-Mektebetü't-Tevfîkıyye, ty.

GAZÂLÎ. Kimya-i Saâdet - Mutluluk Hazinesi. Çeviren A. Faruk Meyan. İstanbul: Bedir Yayınları, 2015.

GAZÂLî. Meâricu'l-Kuds fî Medârici Ma'rifeti'n-Nefs. Beyrut: Dâru'l-Kütübi'lİlmiyye, 1988.

GAZÂLî. Mekâsıdu'l-Felâsife. Beyrut: Dâru'l-Kütübi'l-İlmiyye, 2008.

GAZÂLÎ. "Minhâcü'l-Ârifîn". Içinde Mecmûatü Resâili'l-İmami'l-Gazâlî, 22939. Kahire: el-Mektebetü't-Tevfîkıye, ty.

GAZÂLÎ. "Mi'râcü's-Sâlikîn”. Içinde Mecmûatü Resâili'l-Imami'l-Gazâlî, 50100. Kahire: el-Mektebetü't-Tevfîkıyye, ty.

GAZÂLî. "Mişkâtü'l-Envâr". Içinde Mecmûatü Resâili'l-Imami'l-Gazâlî, 286312. Kahire: el-Mektebetü't-Tevfîklyye, ty.

GAZÂLî. Mi'yâru'l-İlm - İlmin Ölçütü. Çeviren Ali Durusoy ve Hasan Hacak. İstanbul: Türkiye Yazma Eserler Kurumu Başkanlığı, 2013.

GAZÂLÎ. Mîzânü'l-Amel. Kahire: Dâru'l-Meârif, 1964.

GAZÂLÎ. "Ravzatü't-Tâlibîn ve Umdetü's-Sâlikîn". Içinde Mecmûatü Resâili'lImami'l-Gazâlî, 100-174. Kahire: el-Mektebetü't-Tevfîkıyye, ty.

GÜNDÜZ, Şinasi. Hıristiyanlık. İstanbul: İsam Yayınları, 2013.

JAY, Martin. Deneyim Şarkıları. Çeviren Barış Engin Aksoy. İstanbul: Metis Yayınları, 2012. 
Abdullah AKGÜL

OLGUN, Hakan. Sekülerliğin Teolojik Kurgusu: Protestanlık. İstanbul: İz Yayıncllık, 2006.

REÇBER, Sait. Tanrı́yı Bilmenin Imkanı ve Mahiyeti. Ankara: Kitabiyat Yayınları, 2004.

TARNAS, Richard. Batı Düşüncesi Tarihi. Çeviren Yusuf Kaplan. C. 2. İstanbul: Külliyat Yayınları, 2013.

WILLIAMS, Raymond. Anahtar Sözcükler. Çeviren Savaş Kılıç. İstanbul: İletişim Yayınları, 2012.

YARAN, Cafer Sadık. Dini Tecrübe ve Meûnet, Siradan Insanların Sıradışı Dinî Deneyimleri. İstanbul: Rağbet Yayınları, 2009.

深溫 


\section{RELIGIOUS EXPERIENCE AS A JOURNEY TO PERFECTION: AN INQUIRY INTO THE IDEAS OF AL-GHAZALI*}

(1) Abdullah AKGÜL

\section{Extended Abstract}

Religious experience is one of the fundamental problems of the philosophy of religion. Although it has entered the literature as a proof of God; discussions focus on its nature. The basic approaches to the nature of religious experience are: religious experience as a feeling, religious experience as a perception, religious experience as a comment.

The main reason that makes the nature of religious experience controversial is that it consists of two concepts that have a wide range of meaning, such as religion and experience. The meanings that individuals and traditions attach to these two concepts determine the understanding of religious experience. The beginning of religious experience as a term corresponds to the periods of Protestantism. With the emphasis of Enlightenment on the mind, the meanings attributed to religious experience have been reduced and narrowed. In the literature, religious experience is unclear, cannot be transferred to others, instant and extraordinary experiences.

The preliminary acceptance of this article is that the meanings attributed to the term religious experience are narrowed and it is wrong to use the term in the same sense for different traditions. This article assumes that the reader knows the current discussion of the problem. Rather than reacting to the concerns of current debate, it takes a more proactive and pre-opener approach. Rather than reacting to the concerns of the current debate, it takes a more proactive approach to the subject.

This paper will present a different reading of religious experience than the

\footnotetext{
* This article has been derived from the author's master thesis entitled "Religious experience in Al-Ghazali".

a Res. Asst., Erciyes University, dinfelsefesi@gmail.com
} 
Abdullah AKGÜL

literature as a problem of the Philosophy of Religion. In this context, the concept of God, universe and human being in al-Ghazali will be firstly revealed as the ontological background of religious experience; then a description of the concept of religious experience will be proposed on this ontological basis.

If you mean an experience related to religion, which is within religious boundaries with religious experience; Islam for a Muslim, that all experiences that cater to all aspects of human existence and religious boundaries cannot be the person to enter into any human experience that is experienced throughout the religious life. Certainly, here we can talk about the experiences that religion has ordered and forbidden, or in other words, experiences that religion regards as positive or negative.

If an experience related to God is meant for religious experience, here are two cases: when the truth comes to the essence and attributes of God, the human experience does not reach there and in this sense, a religious experience is not possible. If the acts of God are mentioned; all the experiences that people live in are religious in this sense, because everything outside of their own is a deed of God, and whatever happens in the world of being, takes place within God's deeds. Here, too, whether or not people are aware of it, can be mentioned in other words, from conscious and unconscious religious experiences, which is the deciding factor. Faith, then, can be regarded as the first step of the conscious religious experience.

If you are referring to experiences that seem to be unusual for those who are religious and have no religious experience, it is an extraordinary experience to go on a journey itself, compared to not going on a journey. That is to say, the faith itself, which is to ascend to a journey to perfection, is an extraordinary experience compared to those who are not on this path, that is, those who do not have it. For instance for children, the experiences of the elders are extraordinary, and therefore being ordinary and extraordinary is a relative concept. It is necessary to acknowledge the differences in conscious religious experiences mentioned above in the meaning of intense and deep living in themselves. There is a deeper and more intense experience that expresses progress in a journey that leads to God in the sense of the strengthening of faith. This is the kind of experience that most people have not experienced in this sense that the task of the person who is experienced in his own journey is not to stick to them and continue on their way. So living out of order for a Muslim is seen as a barrier that must be encountered and which should not be lingered on, while experiencing something 
extraordinary has a distinctive place for religious experience in current debates. The issue is not that they cannot be explained but they are not deliberately explained due to the fear of misunderstanding. This can be regarded as a method of education that older adults use to train minors.

As a result, if we would define a religious experience according to al-Ghazali, we can say that religion is a journey made towards God, and religious experience is the experience of traveling to God. Traveling to him means to get close to Him, but this approach is not in spatial means but in perfection means. So, religious experience is the journey to perfection of the man himself. Man's perfection is to have the attributes of God who have absolute perfection. These attributes are present in man's own essence. What a person must do, is to place an effort to make these virtual adjectives real.

This journey is basically an existential necessity as it provides the happiness that is essential to human existence. In this journey, which can be understood as becoming a human being who was born as a human being. It should also be added that it is not possible to be absolutely perfect and to reach the reality of God himself in this endless journey of perfection. Therefore, the absolute perfection belongs to God, and it is necessary to understand the concept of perfect human being as a person who has traveled in the journey to perfection.

Keywords: Philosophy of Religion, Religious Experience, al-Ghazali, Journey to Perfection.

$$
\text { 谈谈 }
$$

